\title{
Kedudukan Dan Hak Mewaris Anak Dari Anak Angkat Seorang Pradana Dalam Hukum Waris Adat Bali
}

\author{
Kd Dewantara Rata ${ }^{1}$
}

${ }^{1}$ Fakultas Hukum, Magister Kenotariatan, Universitas Udayana, E-mail : dewantararata.lawyer@gmail.com

\begin{tabular}{l}
\hline Info Artikel \\
\hline Masuk : 2 Juni 2020 \\
Diterima : 14 Juli 2020 \\
Terbit : 6 Januari 2021 \\
Keywords : \\
Keywords: patrilinial, \\
proprietor, heir \\
\\
Korresponding Author: \\
Kd Dewantara Rata, \\
E-mail: \\
dewantararata.lawyer@g \\
Kail.com \\
Kata Kunci: patrilinial, \\
pewaris, ahli waris
\end{tabular}

\begin{abstract}
The people in Bali adhere to the patrilineal kinship system by drawing the lineage of men, hence the son or adopted son, maupu daughter or daughter who changed his status as sentana rajeg as purusa entitled to the inheritance of the heir. It is only in society that the issue of heirs arises regarding the return of a married daughter and re-entry into her original family, whereas in her original family there is a legitimate heir from the heir. The research method in this journal, using normative research specifications, is to provide the most thorough source of human beings, circumstances or other symptoms. The approach used is normative, which is a method that focuses on research into secondary data in the form of primier legal materials, secondary legal materials and tertiary legal materials. The collection of sources of legal materials used in this journal is the study of literature documents and legal journals. Based on the research conducted, that the son of an adopted child of a pradana who enters and lives in his family without going through balinese traditional ceremonies is associated with the customary inheritance law of a position not as an heir from the heir so that it has no right to inherit the inheritance of the heir. Therefore, a prefunder and his offspring will have the same obligation as the heir, while his right is only granted on the basis of volunteering by the rightful heir of the heir.
\end{abstract}

\footnotetext{
Abstrak

Masyarakat di Bali menganut sistem kekerabatan patrilineal yaitu dengan cara menarik garis keturunan laki-laki, oleh karenanya anak laki-laki atau anak angkat laki-laki, maupu anak perempuan atau anak perempuan yang diubah statusnya sebagai sentana rajeg selaku purusa berhak atas harta peninggalan dari pewaris. Hanya saja dalam masyarakat muncul permasalahan pewaris terkait kembalinya anak perempuan yang telah menikah dan kembali lagi masuk ke dalam keluarga asalnya, sedangkan di dalam keluarga asalnya terdapat ahli waris yang sah dari pewaris. Metode penelitian dalam jurnal ini,
} 
DOI :

10.24843/AC.2020.v05.i03.p15 menggunakan spesifikasi penelitian yang bersifat normatif yaitu untuk memberikan sumber yang seteliti mungkin tentang manusia, keadaan atau gejala-gejala lainya. Pendekatan yang dipergunakan adalah normatif yaitu satu metode yang menitikberatkan pada penelitian terhadap data sekunder berupa sumber bahan hukum primier, bahan hukum sekunder dan bahan hukum tersier. Pengumpulan sumber bahan hukum yang dipergunakan didalam jurnal ini yakni studi dokumen kepustakaan dan jurnal-jurnal hukum. Berdasarkan penelitian yang dilakukan, bahwa anak dari anak angkat seorang pradana yang masuk dan tinggal kedaam keluarga aalnya tanpa melalui upacara adat Bali dihubungkan dengan hukum waris adat berkedudukan bukan sebbagai ahliwaris dari pewaris sehingga tidak memiliki hak mewarisi atas harta peninggalan pewaris. Oleh karenanya, seorang pradana dan keturunannya akan mempunyai kewajiban yang sama dengan ahli waris yang dari pewaris, sedangkan haknya hanya diberikan atas dasar sukarela oleh ahli waris yang sah dari pewaris.

\section{Pendahuluan}

Indonesia merupakan negara yang majemuk sebagaimana ternyata dalam semboyan Negara Indonesia yaitu Bhineka Tunggal Ika. Kemajemukan tersebut yang menunjukan bahwa adanya nilai-nilai yang dijadiikan dasar untuk mengatur kehidupan berbangsa dan bernegara dalam menghargai kebhinekaan seperti yang terlihat dari hukum adat yang berbeda-beda disetiap daerah Indonesia.

Hukum adat sebagai sistem hukum merupakan pencerminan jiwa bangsa yang merupakan tradisi pada suatu wilayah hukum adat itu berlaku. Hukum adat tersebut, dapat menunjukan norma-norma kebiasan yang berlangsung dalam kehidupan masyarakat yang tidak berbentuk peraturan perundang-undangan yang dibentuk oleh lembaga legeslatif bersama pemerintah.

Hukum adat lebih banyak memiliki norma-nomra yang tidak terkodifikasi memiliki sifat yang dinamis, statis dan plastis/lentur artinya bahwa aturan adat senantiasa terus berkembang dan berbenah menyesuaikan dengan apa yanag butuhkan oleh masyarakat. Perubahan itu dilaksanakan tidak dengan mewajibkan dan mengganti norma-norma itu dengan norma-norma baru secara tiba-tiba, namun hukum adat senantiasa memenuhi kebutuhan dan tuntutan perkembangan masyarakatnya yang mengarah pada pemenuhan kebutuhan masyarakat.

Sejalan dengan hal tersebut diatas, sesuai dengan apa yang diinginkan oleh bangsa Indonesia untuk menjadikan masyarakat sejahtera, adil dan makmur sesuai dengan amanat Pancasila dan UUD 1945 Amandeen ke-4, maka dalam pembentukan hukum nasional salah satunya berpedoman pada pasal 18 B ayat (2) tertuang dalam UUD 1945 yang mengatur mengenai "hak istimewa" berupa hak hidup yang setara dan 
sama pentingnya, sehingga masyarakat hukum adat mendapatkan perlakuan dan diberikan kesempatan untuk mengembangkan diri untuk maju, dan sejahtera.

Salah satu unsur hukum adat adalah hukum waris adat yang merupakan norma hukum dalam menentukan harta warisan berupa warisan material maupun inmaterial. Masyarakat Bali mayoritas masyarakatnya beragama Hindu dengan sistem kekerabatan yang digunakan adalah patrilineal, sehingga yang berhak mewaris hanya lah anak laki-laki. Sistem kekeluargaan patrilineal adalah sistem kekeluargaan yang menarik garis keturunan pihak nenek moyang laki-laki. Hubungan darah antara anak dan orang tuanya sangat penting untuk diketahui. Hubungan darah adalah pertalian darah yang secara genetis akan membentuk suatu pola enkulturatif yang berarti secara fisik seorang anak akan dilihat menyerupai ibunya atau ayahnya, atau menyerupai neneknya atau kakeknya.

Sistem patrilineal secara aturan merupakan hubungan yang tercipta antara seorang anak dengan garis keturunan bapaknya yang menjadi pedoman silsilah keluarganya, karena merupakan sesuatu yang sangat penting dalam penghidupannya. Menurut Griadi dan Wirawan, bahwa klan atau kerabat pada masyarakat Bali tidak hanya dapat ditelusuri dari hubungan darah diantara mereka menurut garis laki-laki, tetapi dapat pula dilihat dari adanya suatu tempat pemujaan bersama dalam bentuk sanggah atau merajan. Ketentuan tersebut dipercaya bahwa nantinya seorang anak laki-laki akan dapat menyelamatkan orang tuanya dalam dunia maupuan akhirat, seperti yang sering dikatakan dalam kepercayaan adat Bali dimana ada pribahasa " $i$ сиси nyupat $i$ $k a k i "$.

Dalam kenyataanya dapat dijelaskan sebagai berikut : "Pembagian warisan menurut hukum adat Bali tidak saja terjadi setelah pewaris meninggal tetapi hidup pun pembagian warisan itu dapat dilakukan." 1 Pewaris merupakan sesuatu hal yang paing tersulit dalam hukum adat Bali, karena di desa mawacara dalam kehidupan msyarakat adat bali sangat banyak perbedaannya di tiap-tiap desa mengenai banyak sedikitnya pembagian mauapun hal-hal mana saja yang boleh di bagi atau tidak boleh dibagi oleh ahli warisnya, bahkan tentang keputusan pengadilan adat. Lahirnya seorang anak dalam sebuah keluarga dalam hukum adat Bali sering disebut dengan ketunggalan leluhur yang berarti adanya hubungan darah antara seseorang dengan orang lainnya. ${ }^{2}$ Masyarakat adat Bali selain itu mengenal dua bentuk harta peninggalan yaitu harta warisan yang tidak boleh dibagi-bagi berupa sanggah atau merajan, serta harta peninggalam yang diperkenan dibagi-bagi berupa hasil jerih payah pewaris seperti ladang dan sawah ladang beserta lain sebagainya. Atas warisan yang tidak boleh dibagi-bagi inilah, maka kewajiban (swadharma) untuk melaksanakan upacara agama ngaben (pembakaran jenazah) menjadi kewajiban ahli waris seorang purusa, sampai atman-atman leluhur mereka telah berstana di tempat pemujaan keluarga besar (merajan kawitan).

\footnotetext{
${ }_{1}^{1}$ Edo Hendrako, (2015), Hak Waris Anak Perempuan Terhadap Harta Peninggalan(Studi Kasus Putusan MA RINO.4766/Pdt/1998), Lex Privatum,3(1), 89

2 Ni Nyoman Sukerti (2012). Hak Mewaris Perempuan Dalam Hukum AdatBali Sebuah Studi Kritis. Denpasar: Udayana University Press. p.8
} 
Berdasarkan hukum waris adat Bali, laki-laki atau purusa harus melakukan kewajibankewajibannya baik dalam segi keagamaan dan segi adat terhadap kewajiban pewaris, berupa keluarga serta kehidupan bermasyarakat adat, seperti menggantikan peran bapaknya didalam kehidupan masyarakat untuk menjalankan kewajibankewajibannya sebagai anggota dalam kesatuan kehidupan bermasyarakat hukum adat.

Pengangkatan anak di Indonesia merupakan kebutuhan masyarakat dan menjadi bagian dari sistem hukum kekeluargaan. ${ }^{3}$ Bilamana suatu keluarga bila hanya mempunyai satu atau kesemua anaknya merupakan anak perempuan dan serta tidak memiliki anak laki-laki, maka dapatlah anak perempuan tersebut diganti statusnya dijadikan anak laki-laki dengan istilah sentana rajeg dengan melakukan perkawinan nyentana atau nyeburin, serta status anak perempuan tersebut disamakan dengan anak laki-laki agar bisa mewarisi warisan orang tuanya.

Di Indonesia pengangkatan anak sudah menjadi kebutuhan masyarakat serta menjadi bagian dari implementasi sistem hukum kekeluargaan, karena menyangkut kepentingan orang perorang dalam keluarga. ${ }^{4}$ Bagi keluarga yang tidak ada keturunan laki-laki dalam keturunannya, maka dilakukan pengangkatan anak yang berfungsi sebagai penerus generasi atau keturunan, proses penganggkatan anak ini, dilakukan upacara pemerasan dan diumumkan di hadapan masyarakat, yang ditujukan agar menghilangkan status awal anak itu dari seluruh ikatan serta semua hubungannya dengan orang tua asli serta sekaligus membuat anak tersebut menjadi anak dari keluarga yang sudah mengangkatnya. Anak yang telah diangkat khususnya di Bali langsung memiliki hak secara penuh dan setara dengan anak kandung terhadap harta orang tuanya dan juga anak angkat tersebut memiliki kewajiban yang sama rata dan sebagai mana layaknya yang berlaku untuk anak kandung.

Sehingga permasalahan yang muncul dan akan penulis bahas dan teliti dengan tujuan yang diharapkan untuk lebih jelas dan mempermudah pemahaman terhadap permasalahan bagaimanakah kedudukan anak dari anak angkat serang pred ana yang masuk dan tinggal kedalam keluarga asalnya tanpa melalui upacara adat bali dihubungkan engan hukum waris adat.

\section{Metode Penelitian}

Metodelogi merupakan penelitian hukum yang menjelaskan mengenai prosedur seubah riset hukum yang dilakukan untuk mendapatkan suatu hasil riset yang telah teruji kepastiannya. Suatu riset hukum dapat dilaksanakan menggunakan sudut pandang ilmu hukum agar dapat menemukan norma-norma ataupun kaidah hukum, sehingga dari sudut pandang inilah kita dapat menemukan jawaban-jawaban atas masalah-masalah yang sedang diangkat. ${ }^{5}$ Tulisan jurnal ilmiah terhadap Kedudukan dan Hak Mewaris Anak dari Anak Angkat seorang Pradana dalam Adat Bali dihubungkan dengan ketentuan Hukum Waris Adat dapat dikatakan sebagai

\footnotetext{
${ }^{3}$ Haedah Faradz, (2009), Pengangkatan Anak Menurut Hukum Is lam, Jurnal Dinamika Hukum 9(2), 155

${ }^{4}$ Sumiati Usman, (2013), Kedudukan Hukum Anak Angkat TerhadapHak Waris, Lex

Privatum, 1(4), 136

${ }^{5}$ Marzuki, P.M (2005), Penelitian Hukum, Jakarta: Prenada Media. p. 35
} 
penelitian hukum normatif dengan memakai pendekatan hukum yang berlaku saat ini dan pendekatan konseptual.

Dalam penulisan jurnal ini menggunkan sumber bahan hukum yang meliputi data sekunder mencangkup bahan hukum primer seperti undang-undang perkawinan. Bahan hukum sekunder ini berisi penjabaran dari sumber hukum primer berupa hasil riset yang diperoleh dari ilmu hukum. Selain bahan hukum itu digunakan pula bahan dari sumber hukum tersier yang memuat penjelasan dan petunjuk yang berhubungan dengan sumber bahan hukum primer dan sekunder seperti ensiklopedia dan kamus. Susunan bahan hukum ini memakai cara-cara menganalisa berupa interpretasi, deskripsi, evaluai, sistematis, serta gagasan yang berkenaan dengan Kedudukan dan Hak Mewaris Anak dari Anak Angkat seorang Pradana dalam Adat Bali duhubungkan dengan ketentuan Hukum Waris Adat.

\section{Hasil Dan Pembahasan}

\subsection{Pengangkatan Anak Oleh Seorang Pradana Pada Masyarakat Adat Bali}

Ada beberapa istilih yang digunakan dalam pengangkatan anak yang ada didalam hukum adat dibali seperti ngidih sentana, meras sentana, meras pianak, ngidih pianak. Kata "sentana" atau "pianak" yang memiliki makna keturunan atau bisa dikatakan anak sertaa dalam kata "ngidih" memiliki makna meminta atau "meras" yang bersumber dari kata "peras" dapat digambarkan seperti persembahan untuk upakara sebagai saksi bahwa si anak tersebut sudah masuk kedalam keluarga barunya.

Pengertian pengangkatan anak di Bali hampir serupa seperti pengangkatan anak yang di kemukakan oleh ahli hukum adat, defenisi pengangkatan seorang anak yang diterapkan oleh masyarakat adat di Bali dapat dijabarkan seperti berikut :

1. Adanya suatu tindakan melepaskan anak dari asuhan, pengawasan dan kewenangan orang tua kandung, yang artinya ada keinginan yang diminta oleh calon orang tua angkat terhadap orang tua kandung atau kerabatnya si anak untuk dilepaskan dari kewenangan orangtua kadung dan dilanjutkan engvan memasukakan anak tersebut ke dalam orang tua angkatnya untuk melanjutkan ahli warisnya. Kemudian dilakukan siar yaitu pemberitahuan yang peruntukkan pada masyarakat adat setempat.

2. Adanya kegiatan upacara pengangkatan anak (pemerasan). Dalam praktek keagamaan dan adat bali, kegiatan ini mengartikan bahwa anak yang diangkat akan lepas kewenangannya dari orang tua kandung, kerabat dan ataupun leluhur asalnya kemudian dilanjutkan dengan memasukan kedalam lingkungan orang tua baru yang mengangkatnya. Maka dari itu secara hukum dapat dikatakan anak yang sudah diangkat tidak lagi ada hubungan kewarisan terhadap orang tua aslinya melainkan akan mendapatkan hubungan waris dengan orang tua angkatnya.

Tujuan melangsungkan perkawinan adalah untuk melahirkan keturunan yang suputra, yang diharapkan bisa mengangkat harkat dan martabat orang tua, meneruskan peribadahan keluarga, seperti melaksanakan upacara persembahyangan di sanggah atau merajan, serta melakukan ritual pemujaan kepada leluhur agar hidup senantiasa rukun dan damai. Atas dasar tujuan itu, 
bilamana dalam suatu keluarga tidak dapat memiliki keturunan, hal yang biasanya dilaksanakan adalah mengangkat anak dengan alasan untuk meneruskan serta mempertahankan kelangsungan hidup suatu keluarga agar tidak terputus.

Makna pengangkatan anak menurut ajaran agama Hindu, yaitu :

1. Melanjutkan kewarisan, dalam ajaran Agama Hindu Bali yang dapat dikatakan warisan adalah semua tentang hak dan kewajiban diamana semua itu menyangkut tentang Tri Hita Karana, anak yang sudah angkat tidak hanya mewarisi harta bergerak dan tidak bergerak yang memiliki ekonomis tinggi, akan tetapi secara otomatis mendapatkan kewajiban yang sama dengan anak kandung.

2. Menyelamatkan roh leluhur, seperti yang dijelaskan dalam Manawa Dharmasastra IX.138 menyebutkan, bahwa : karena anak yang akan menyelamatkan orang tua dari neraka jahanam yang dikatakan ceput yang disebabkan karena tidak memiliki penerus. Maka dari itu ia dinamakan putra.

3. Pengikat tali cinta kasih keluarga, dengan adanya anak yang terlahir atau anak angkat didalam kehidupan keluarganya dapat dikatakan sebagai pengikat tali kasih didalam keluarga.

Pengangkatan anak di Bali disesuaikan dengan sitem patrilineal, artinya keturunan selalu ditarik hanya melalui garis keturunan kepurusa. Pasrawa Residen Lombok dan Bali 1900 yang tertuang dalam pasal 11, telah ditentukan syarat pengangkatan anak, dikatakan bahwa seseorang dapat mengangkat anak dari berasal dari keluarga purusa yang paling dekat serta yang jauh pada garis keturunan kedelapan, selain memenuhi peryaratan dimaksud dapat mengangkat anak diluar keluarga, akan tetapi harus disetujui oleh keluarga besar serta telah mendapatkan ijin dari instansi yang berwenang.

Dalam hukum adat Bali yang diperbolehkan untuk diangkat menjadi anak angkat adalah anak laki-laki, namun hal tersebut dapat diterobos dengan pengangkatan terhadap anak perempuan, apabila anak perempuan yang sudah dinyatakan sah sudah sah menjadi anak angkat, maka anak yang dimaksud dapat dikatakan berstatus menjadi seorang anak laki-laki serta anak tersebut tetap memiliki hak mewaris setelah anak tersebut melakukan perkawinan nyeburin yang mengubah status anak perempuan sebagai sentana rajeg, sehingga anak tersebut berhak mewarisi warisan tersebut bersama-sama dengan saudaranya yang belum melaksanakan perkawinan.

Dalam hal yang melaksanakan pengangkatan anak adalah pasangan suami istri yang beragama Hindu, maka sudah sepatutnya dalam proses mengangkat anak sudah sepantasnya mengikuti norma-norma ataupun aturan-atiran yang diberlakukan didaerahnya masing-masing, sehingga proses mengangkat anak harus berdasarkan aturan Undang-undang yang digunakan di Indonesia.

Tata cara menggangkat anak atau mengambil anak didalam adat Bali menggunakan tahapan-tahapan sebagai berikut :

1. Orang yang berkeinginan melaksanakan pengangkatan anak harus memusyawarahkan keinginannya kepada keluarga besarnya secara masak-masak.

2. Seorang anak yang diinginkan untuk diangkat, harus memutus hubungan adat serta hubungan kekeluargaannya terlebih dahulu dengan orang tua kandung atau kerabatnya. Dengan cara memutus tali persaudaraan yang dalam adat bali 
menghaturkan penanjung batu (membayar kompensasi) sebagai simbol hubungan anak dengan ibu telah terputus.

3. Kemudian anak yang akan diangkat dimasukan ke dalam garis keturunan kekeluargaan dari calon orang tua yang akan mengangkatnya, dengan melakukan upakara pemerasan (upacara pengesahan).

4. Pengumuman kehadapan warga desa, biasanya pengumuman ini dilaksanakan bersamaan dengan rapat rutin bulanan krama banjar sehingga tersisip pada saat rapat banjar tersebut di umumkan kepada seluruh masyarakat banjar adat bahwa ada seseorang yang telah melaksanakan pengangkatan anak.

Pasal 11 ayat (4) Pasrawa Residen Bali dan Lombok 1900, disebutkan bahwa : “tiap transaksi pengangkatan anak sentana harus dibuatkan surat di kantor kepala Kabupaten (controlir)."

\subsection{Analisis Kedudukan Dan Hak Mewaris Anak Dari Anak Angkat Seorang Pradana Dalam Adat Bali Dihubungkan Dengan Ketentuan Hukum Waris Adat.}

Waris memiliki peranan yang sangat penting dalam kehidupan umat manusia. ${ }^{6}$ Pewarisan yang berlaku dalam umat Hindu Bali berpedoman pada kitab suci agamanya, antara lain kitab Manawa Dharmasastra, Weda Smrti atau Manu Smrti, yang dalam pelaksanaanya dipengaruhi oleh bentuk susunan masyarakat yang bersifat patrilineal yang berarti mengikuti garis keturunan bapak. Ahli waris untuk di Bali identik dengan sentana, yang berarti pelanjut Keturunan. ${ }^{7}$ Berdasarkan sistem patrilineal ini, maka posisi anak laki-laki lebih diprioritaskan daripada anak perempuan, karena anak laki-laki mempunyai hak dan kewajiban yang lebih tinggi daripada perempuan. Seperti hukum adat di bali dengan corak sistem kekerabatan parilineal yang begitu kuat, kehadiran anak (laki-laki umumnya) sangat penting untuk pelanjut keturunan baik dalam kehidupan sosial dan ekonomi. Hal inilah yang menyebabkan "keluarga patrilinial tidak akan berhenti "membuat anak" jika belum dikarunia pelita hati laki-laki sebagai penerus treh keluarga." 8

Berdasarkan sistem waris Hindu dapat diresepir di dalam bentuk hukum waris adat Bali, Terdapat berbagai asas yang berhubungan dengan kedudukan ahli waris yakni :

1. Asas anak lelaki yang memiliki hak sebagai ahli waris.

2. Asas hanya keturunan (anak) saja yang berhak menjadi ahli waris.

3. Asas pergantian dari pewaris kepada ahli warisnya hanya dapat terjadi apabila orang tua telah meninggal.

4. Asas berlakunya hereditas petition maksudnya bahwa kedudukan ahli waris secara formal berhak menuntut pelaksanaan pembagian waris walaupun pewaris masih hidup.

Pada asasnya menurut hukum waris adat Bali, harta warisan beralih bila sipewaris terhadap ahli warisnya memiliki hubungan sedarah.

\footnotetext{
${ }^{6}$ Ni KadekSetyawati,(2017), Kedudukan Perempuan Hindu Menurut Hukum Waris Adat Bali Dalam Perspektif Kesetaraan Gender, Institut Hindu Dharma Negeri Den pasar, 1(2), 618

${ }^{7}$ I Gede Surata, (2019), Kedudukan Ahli Waris Predana Menurut Hukum Adat Bali Hubungannya Dengan Hak Atas Tanah Terkait Dengan Pesamuan Agung III Tahun 2010, Kertha Widya, 7(2), 23

${ }^{8}$ Ni Ketut Sari Adnyani, (2016), Bentuk Perkawinan Matriarki Pada Masyarakat Hindu Bali Ditinjau Dari Perspektif HukumAdat Dan Kesetaraan Gender, Jurnal Ilmu sos ial dan Humaniora, 5(1), 756
} 
Laki-laki yang mendapat hak untuk mewarisi peninggalan orang tuanya, yaitu:

1. Anak laki-laki yang bujang kawin dengan seorang dara (gadis) atas dasar suka sama suka yang di upacarakan menurut adat dan agama.

2. Anak laki-laki yang dilahirkan dari istri janda dan telah lama kawin dengan ayahnya dan harta pencaharian mereka sudah menjadi satu.

3. Anak laki-laki pemberian saudara atau pemberian saudara.

4. Anak yang diminta dari orang lain untuk dijadikan sentana (anak angkat).

5. Anak laki-laki itu terlahir dari istri yang tidak punya anak yang di izinkan suaminya bersetubuh dengan peria lain.

6. Anak yang dibuang oleh ibu bapaknya lalu dipunggut oleh orang lain dan diakui sebagai anak.

Sistem waris-mewaris berdasarkan ajaran agama Hindu dan adat Bali utamanya yang diimplementasikan oleh orang-orang Hindu Bali berdasarkan kaidah-kaidah yang tertuang didalam buku-buku agamanya. Oleh karenanya menurut agama Hindu karenanya yang dimaksudkan ahli waris menurut ajaran agama Hindu diutamakan adalah anak laki-laki, sebab jika menganut kepercayaan hindu yang bisa menyelamatkan arwah leluhurnya dari ancaman neraka hanyalah anak laki-laki.

Masyarakat Bali pada umumnya menganut sistem kekeluargaan patrilineal. ${ }^{9}$ Anak laki-laki tertua dalam sistem keluargaan hindu, tetap dihormati, sehingga kemungkinan yang akan terjadi ialah anak laki-laki dikemudian hari akan menjadi pemimpin dan melakukan penguasaan atas harta yang ditinggalkan oleh orang tuanya atau jika dilakukan pembagian atas harta peninggalan tersebut, maka anak laki-laki tertua mendapat bagian lebih banyak dari pada saudara-saudara lainnya. Jadi, yang dimaksud dengan pewaris dalam agama Hindu adalah anak laki-laki tertua, hal ini sebagai mana diatur dalam Manawa Dharmasastra Veda Smrti Buku IX.

Keluarga masyarakat adat Bali yang tidak mempunyai keturunan laki-laki melainkan hanya memiliki anak perempuan, dalam hukum hindu dibolehkan untuk merubah status anak perempuannya dirubah menjadi anak laki-laki. Peningkatan status anak perempuan ini sebagai upaya hukum untuk menentukan secara formal bahwa anak perempuan dapat dijadikan ahli waris dengan hak penuh seperti anak laki-laki. pergantian status anak dari laki-laki menajdi perempuan ini bisa timbul karena adanya 2 (dua) hal, yaitu :

1. Menurut kepercayaan Hindu, hanyalah anak laki-laki yang dapat dan bisa menyelamatkan arwah maupun roh leluhur kelak bila sudah meninggal. Berdasarkan kepercayaan ini, maka merubah status seorang anak perempuan menjadi anak laki-laki bukan hanya didasarkan atas pertimbangan warisan melainkan juga pertimbangan agamis.

2. Menurut hukum hindu, perubahan status anak perempuan menadi anak laki-laki bersifat formil dan tujuannya adalah untuk melangsungkan dan meneruskan garis keluarga. Jadi menyangkut unsur pewarisan. Hukum inilah yang disebut hukum sentana didalam hukum adat waris, yang dasarnya adalah hukum Hindu. Sebagai

\footnotetext{
${ }^{9}$ I Putu Windu Mertha Sujana, (2017), Pelaks anaan Perkawinan Nyentana DalamRangka Mengajegkan SistemKekeluargaan Patrilineal DiBali, Jurnal Kajian Pendidikan Widya Accarya FKIP Universitas Dwijendra, 7(1), 3
} 
akibat dari perubahan status anak perempuan menjadi anak laki-laki, maka status hukumnya berubah sebagai status anak laki-laki pula.

Menurut Satrio "akibat dari pengangkatan anak dalam hukum adat di Bali adalah bahwa anak itu mempunyai kedudukan sebagai anak yang lahir dari suami istri yang mengangkatnya, sama seperti anak kandung dan hubungan dengan keluarga dengan keluarga asalnya menjadi putus."10

\section{Kesimpulan}

Berdasarkan penelitian yang dilakukan penulis dalam tesis ini, sehingga penulis menyimpulkan sebagai berikut:

Kedudukan anak dari anak angkat seorang pradana yang masuk dan tinggal kedalam keluarga asalnya tanpa melalui upacara adat Bali dihubungkan dengan hukum waris adat, bahwa dalam hukum adat dibali dan hukukm Hindu, anak perempuan yang berstatus pradana bukanlah sebagai ahli waris dari pewaris sehingga tidak memiliki hak atas harta peninggalan pewaris. Mereka yang berstatus pradana dengan melaksanakan perkawinan keluar dan kembali kerumah asalnya tidak dapat dikembalikan statusnya seperti sebelum menikah dan hanya dapat "diajak"oleh ahli waris yang sah dari pewaris, oleh karenanya hanya akan mempunyai kewajiban yang sama dengan ahli waris yang sah dari pewaris.

\section{Daftar Pustaka / Daftar Referensi}

Buku

Marzuki, P.M (2005), Penelitian Hukum, Jakarta: Prenada Media.

Sukerti, Ni Nyoman, (2012), Hak Mewaris Perempuan Dalam Hukum Adat Bali Sebuah Studi Kritis, Denpasar: Udayana University Press.

\section{Jurnal}

Compedium Hukum Departemen Agama RI, Rg Veda VIII Dan Terjemahannya, PT. Mayasari , Jakarta.

Edo Hendrako, (2015), Hak Waris Anak Perempuan Terhadap Harta Peninggalan (Studi Kasus Putusan MA RI NO. 4766/Pdt/1998), Lex Privatum, 3(1).

Haedah Faradz, (2009), Pengangkatan Anak Menurut Hukum Islam, Jurnal Dinamika Hukum 9(2).

I Gede Surata, (2019), Kedudukan Ahli Waris Predana Menurut Hukum Adat Bali Hubungannya Dengan Hak Atas Tanah Terkait Dengan Pesamuan Agung III Tahun 2010, Kertha Widya Jurnal fakultas Hukum UNIPAS, 7(2)

I Putu Windu Mertha Sujana, (2017), Pelaksanaan Perkawinan Nyentana Dalam Rangka Mengajegkan Sistem Kekeluargaan Patrilineal Di Bali, Jurnal Kajian Pendidikan Widya Acarya FKIP Universitas Dwijendra, 7(1).

${ }^{10} \mathrm{~J}$. Satrio, (2000). Hukum Keluarga Tentang Kedudukan Anak Kandung Dalam Undang-Undang.

Bandung: Citra Aditya Bhakti, p. 262 
Sumiati Usman, (2013), Kedudukan Hukum Anak Angkat Terhadap Hak Waris, Lex Privatum, 1(4).

Ni Kadek Setyawati, (2017), Kedudukan Perempuan Hindu Menurut Hukum Waris Adat Bali Dalam Perspektif Kesetaraan Gender, Institut Hindu Dharma Negeri Denpasar, 1(2).

Ni Ketut Sari Adnyani, (2016), Bentuk Perkawinan Matriarki Pada Masyarakat Hindu Bali Ditinjau Dari Perspektif Hukum Adat Dan Kesetaraan Gender, Jurnal Ilmu sosial dan Humaniora, 5(1). 